Identification of Distribution the Pineapple

\title{
Mealybug Wilt Disease in the Pineapple plant in North Tapanuli
}

\author{
Arta Junita Hutahayan, SP, Msi \\ Universitas Sisingamangaraja XII Tapanuli
}

\begin{abstract}
Pineapple is one of the commodities of horticultural crops of fruits that have been developed by generations of people in the North Tapanuli Regency. Pineapple is a commodity mainstay of the community, where the planting spread in several districts, such as Sipahutar, Pangaribuan, Siborongborong and Tarutung. Sipahutar District is a pineapple production center in North Tapanuli Regency. Pineapple from Sipahutar, famous since the first because it has advantages compared with other pineapple that has a sweeter taste, water content slightly and texture more dense. The problem in pineapple cultivation lately is wilting mealybug disease because the losses incurred are very large. The purpose of this study was to detect and study infections from mealybug wilt disease in the field and the spread of mealybug wilt disease in some villages of pineapple planting centers in North Tapanuli region. The results of this study are expected to be information in controlling mealybug wilt disease in pineapple plants.
\end{abstract}

Keyword-Mealybug, North Tapanuli, Pineapple Disease, Wilt Symptom.

\section{INTRODUCTION}

Pineapple (Ananas comosus) is a commodity mainstay of society in North Tapanuli Regency. The most dominant pineapple planting is in Sipahutar, Pangaribuan, Siborongborong and Tarutung sub-districts, which are pineapple production centers in North Tapanuli Regency (TUDA, 2015). Pineapple found in North Tapanuli has advantages of pineapple contained in other areas such as those produced from Garut. Since long time, pineapple plant produced from Garut region is famous but compared with pineapple from North Tapanuli regency, Garut pineapple quality is still far below pineapple Tapanuli Utara (TUDA, 2015)

The North Tapanuli Pineapple is large and sweet, red and has plenty of water. Pineapple fruit in canned packaging from North Tapanuli Regency is also exported to several countries such as China, Taiwan, America and Sweden. The exported pineapple is the fruit of the crops of farmers in almost every sub-district in North Tapanuli namely
Sipahutar, Pangaribuan, Siborong-borong and Tarutung (TUDA, 2015).Seeing pineapple as one of the much needed horticultural products, especially the North Tapanuli community, it is necessary to improve the quality and quantity of pineapple plants, and to follow up it is necessary to know the determinants of production such as soil, climate, plant species, cultivation techniques and pests and pineapple plant disease. One of the main problems in the cultivation of pineapple plants is the disease of wilting mealybug This disease has significance because of the wide spread area that is in the entire pineapple planting region of the world, but it also caused considerable losses (Pretty et al., 2012). The spread of this disease is almost in the entire pineapple planting regions of the world including Indonesia, not least the central pineapple planting area of North Tapanuli (CABI 2013). However, there is not enough information on this disease. Based on the observation, this disease is one of the important problems in pineapple plantation of PT Great Giant Pineapple Company in Lampung, the same thing happened in North Sumatra. This disease causes damage and rot to rooting. Symptoms seen in affected plants are to wither, red color on the leaves starting from the outermost, dwarf fruit and even death of the plant.

So far, control measures are still based on chemical methods. The main target is to control vector insects Dysmicoccus spp and ants as a tick symptom. But this way can be bad for people and the environment. In addition, consumer demand at this time wants the use of pesticides to a minimum, especially for consumers in developed countries. Biological control is an alternative and an important control component in Integrated Pest Management (IPM). Nevertheless, information on the existence of natural enemies of this pest in Indonesia is still very limited. For that we need a study about the detection and spread of the disease in order to support effective control efforts. This study aims to detect and study infections from Mealybug wilt disease in the field and the spread of mealybug wilt disease in some villages of pineapple planting centers in North Tapanuli region. 


\section{LITERATURE REVIEW}

Mealybug wilt disease was first recognized in 1910 in Hawaii. In the 1920s and 1930s almost destroyed the pineapple canning industry in Hawaii. Some of the data below mention that the decline in production caused by this wilting disease is quite high. Pretty et al. (2012) in Cuba suggests a yield loss of $40 \%$, according to Sether et al. (2001), $\mathrm{Hu}$ (2001), the decrease\&yield loss of 35\%, even according to Sether in yields can also be experienced by asymptomatic plants that are asymptomatic. In addition to causing a decrease in yield, this wilting disease may also lead to early ripening of the fruit (Sipes et al., 2002). In plants infected with wilting mealybug disease there was a decrease of average weight of fruit by $55 \%$ when compared with plantsybug diseasefree plants. If Mealybug wilt disease develops 14 months after planting, the resulting fruits weigh an average of \pm $7 \%$ less than plants that are free from Mealybug wilt disease (Sether and $\mathrm{Hu} 2002$ ).

Symptoms of the disease first appear in rooting roots that are impaired growth, collapse and decomposition, followed by wilting symptoms in the leaves. Collins (1960) divides symptoms of wilt disease on this pineapple into four stages. The first stage is a reddish leaf that starts from the outer leaves (third or fourth leaf), the edges of the leaves are rolled up, the tip of the leaf is not curved and the plant still looks normal. The second stage, the leaves are reddish, turgiditas begin to disappear, the tip of the leaves slightly brownish, sometimes leaf curling and occur nekrotis with the size of the plant is still normal. The third stage, the fourth and fifth circumference leaves bend down, the edges of the leaves are yellow or reddish, the edges curl backward and the plant is dwarfed. The fourth phase, the middle leaves look erect but have lost the turgidity, the leaf tips are bent and brown, curly leaves and dwarf plants. The wilted disease in pineapple is caused by a virus belonging to the Closteroviridae family and the Closterovirus genus. At first known, the disease was thought to be due to the presence of toxins produced by Dysmicoccus spp during feeding (Carter 1973), then further the presence of latent factor transmitted by ticks and in the 1980s was successfully isolated from plant virus ill (CABI 2013). Another commonly used name is Pineapple Mealybug Wilt associated Closterovirus. Until now it has been found a type of virus associated with this wilting disease. First discovered pineapple closterovirus (PCV) in the 1980s, then because the pineapple wilt disease is always associated with white fleas, the disease is called mealybug wilt of pineapple (MWP), which is then revised into pineapple mealybug wilt associated virus. Furthermore, the last research managed to find a rod-shaped virus or baciliform (CABI 2013). Transmission of the virus cannot occur mechanically, but must be with the help of vectors. This is the importance of the role of vector insects. Insects that can be viral vectors are D.brevipes, D.neobrevipes and Pseudococcus longispinus. Transmission is semi-persistent and nontransovarial (Brunt and Gunasinghe, 1991). Factors affecting the epidemic are complex, including multiple interactions between mealybugs, ants, predators, parasites, viruses, pineapple plants and other plants as alternative hosts such as Agavae americana and Paspalum weeds. Symptomatic expression is also influenced by environmental conditions and diversity of mealybug populations (Rohrbach et al., 1988). Mealybug is usually associated with ants. Ants maintain and protect mealybugs from predators by eating honey dew generated by mealybugs, also preventing the development of sooty dew caused by fungi (Beardsley et al., 1982).

\section{Data and Source of Data}

Study of transmission of wilt disease mealybug in the field. Identifying the role of wilt disease and mealybug in inducing wilt symptoms in pineapple plants in the field, then observations were made on pineapple plantations in Sipahutar Village Village, North Tapanuli Regency. The observed pineapple garden is a garden with an incidence of wilt disease of more than $50 \%$. In selected gardens were observed a number of symptomatic plants withered and asymptomatic ones. In each plant sample, both symptomatic and asymptomatic, were observed for mealybug colonization for 5 months.

\section{Data Collection Method}

Mapping the geographic distribution of pineapple wilt disease. The observation of mapping of pineapple wilt disease by mealybug was conducted through surveys of pineapple in several central districts of pineapple production in North Tapanuli region, Pangaribuan, Siborongborong and Tarutung subdistricts, to observe the spread of wilt disease and variation of wilting symptoms. In each area of pineapple production centers were observed some pineapple gardens owned by local farmers. In each selected garden were observed the incidence rate of the disease and the type of wilting symptoms in the pineapple plant. This data is expected to map the spread of wilt disease in pineapple growing areas in North Tapanuli.

\section{RESULTS OF DISCUSSION}

1. Study of transmission of wilt disease mealybug in the field

Observations of the studies determined to observe transmission of pineapple wilt disease in the field were in Pealinta Hamlet, Siabal-abal III, Sipahutar, North Tapanuli. In the area, pineapple planted mostly varieties of Smooth Cayenne. 


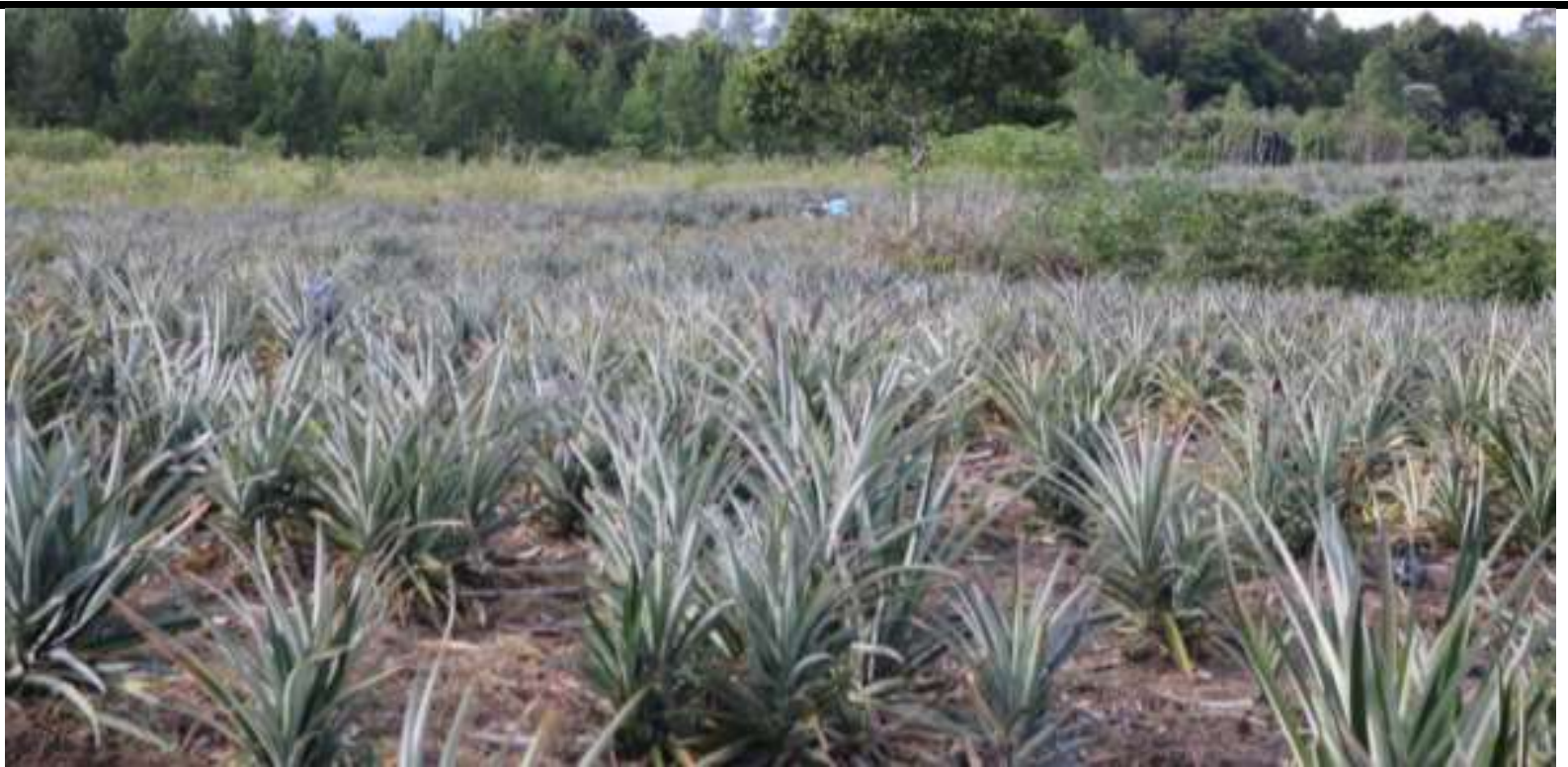

Fig.1: Location of pineapple plantation in Pealinta Hamlet Siabalabal Sipahutar Village

This variety has the following characteristics, stem height and fruit stalk about $20-50 \mathrm{~cm}$. The number of leaves ranges from 60-80 strands. Leaves are shallow trough shape with straight edge, not wavy. The fruit is at the end of the fruit stalk with the lower part larger than the tip. Fruits weighing above average shapes are tapered from base to tip, while fruits weighing below average are near the cylinders. The upper leaf surface is dark green with the addition of irregular brownish red color due to antocyanin pigment in the epidermis.

At the location of this observation found widespread symptoms of widespread and most wilting symptoms are yellow wilt symptoms and curling at the tip of the plant leaves.

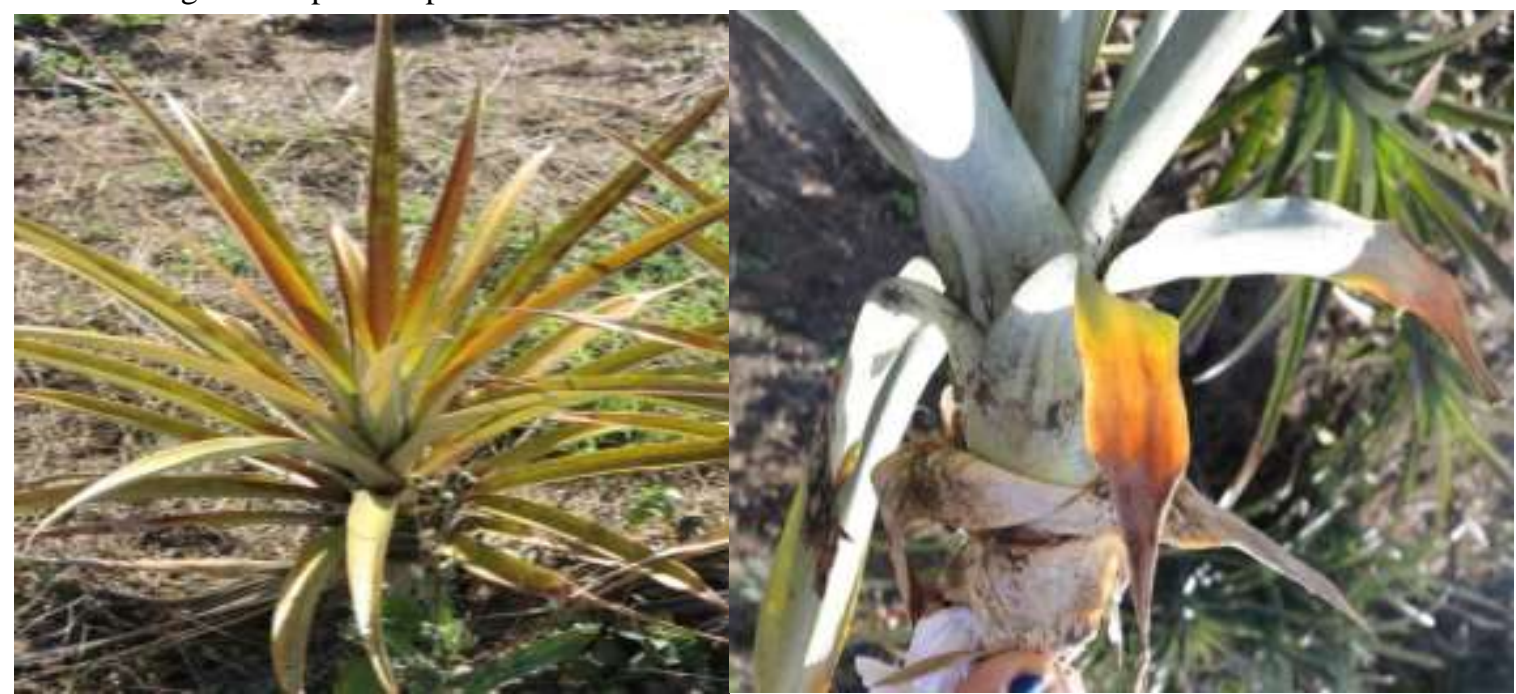

a.Yellow

b. Curled at the tip of the plant leave

Fig.2: The pineapple plant was symptomatic withered on the research field

In the wilted pineapple plants observed in this area, the presence of white flea colonization (D. brevipes) was observed. Mealybug are found at the base of the leaf near the pineapple plant stems and are also found at the bottom of the base of the pine plant stems close to the roots of the pineapple plant. 


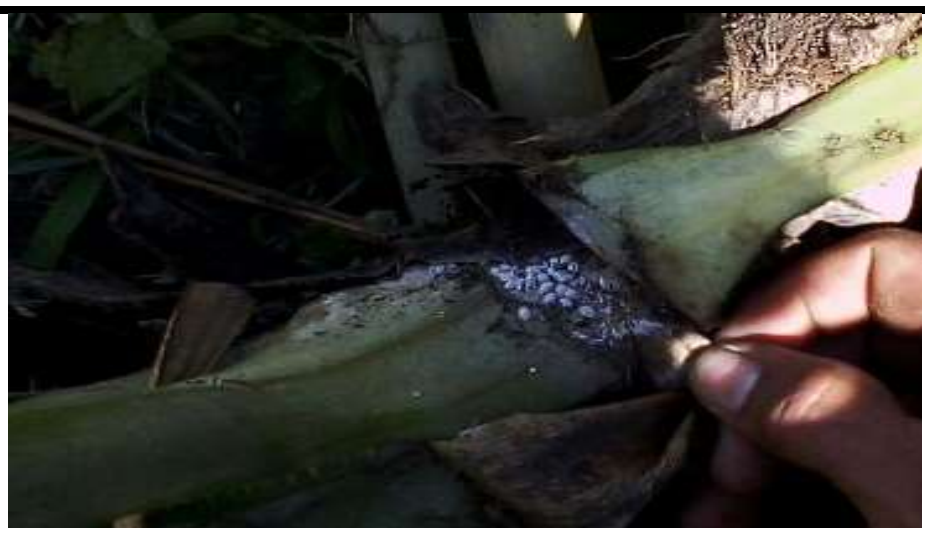

Fig.3: Mealybug colonies (Dysmicoccus brevipes)

Percentage of pineapple plants in the field showing symptoms of wilt and / or colonization of white fleas

\begin{tabular}{|c|l|r|}
\hline No & \multicolumn{1}{|c|}{ Individual pineapple plant observed Percentage } & Persentage \\
\hline 1 & Showing symptoms of wilting and colonization of mealybug & 71 \\
\hline 2 & Showing symptoms withered but uncolonized white fleas & - \\
\hline 3 & Colonized white but healthy looking lice (not showing symptoms wither) & 14 \\
\hline
\end{tabular}

\section{Mapping the geographic distribution of pineapple wilt disease}

Mapping distribution of wilt disease mealybug by mealybug was conducted through a survey to pineapple plantation in the central area of pineapple production in North Tapanuli, namely Tarutung, Pangaribuan and Siborongborong Subdistricts.

2.1. Incidence of wilt disease in pineapple production center Tarutung Subdistrict (Desa Siarang-arang).

In this planting pineapple pineapple varieties Smooth Cayenne and in this area found quite a lot of wilting symptoms with two variations of wilting symptoms are symptoms of wilting and wilting symptoms with dead ends.

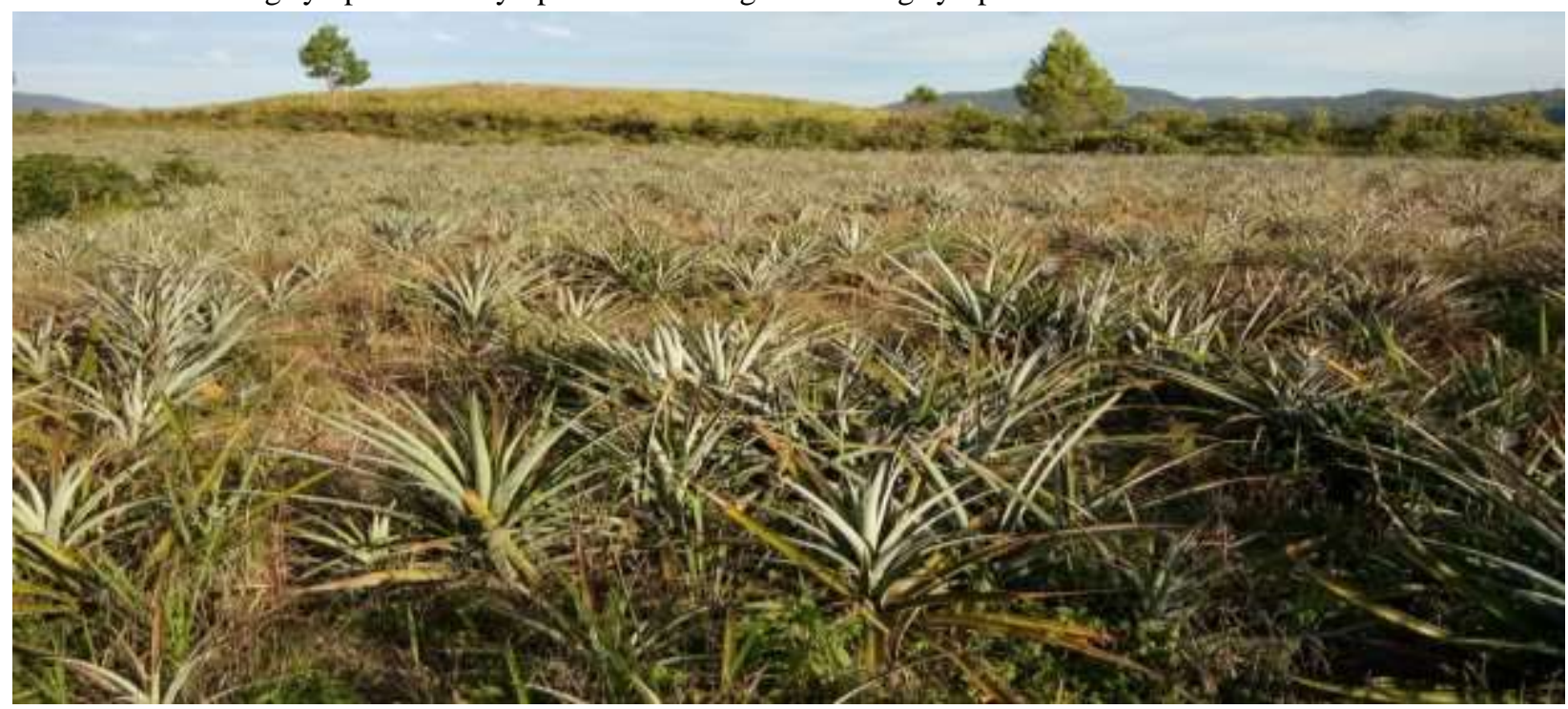

Fig.4: Location of pineapple plantation in Siarangarang Village Tarutung Sub-district

In all pineapple plants observed and showing wilting symptoms, colonization of mealybug was found at the base of the pineapple plant stem, in the lower leaf axilla or in the root of the plant 


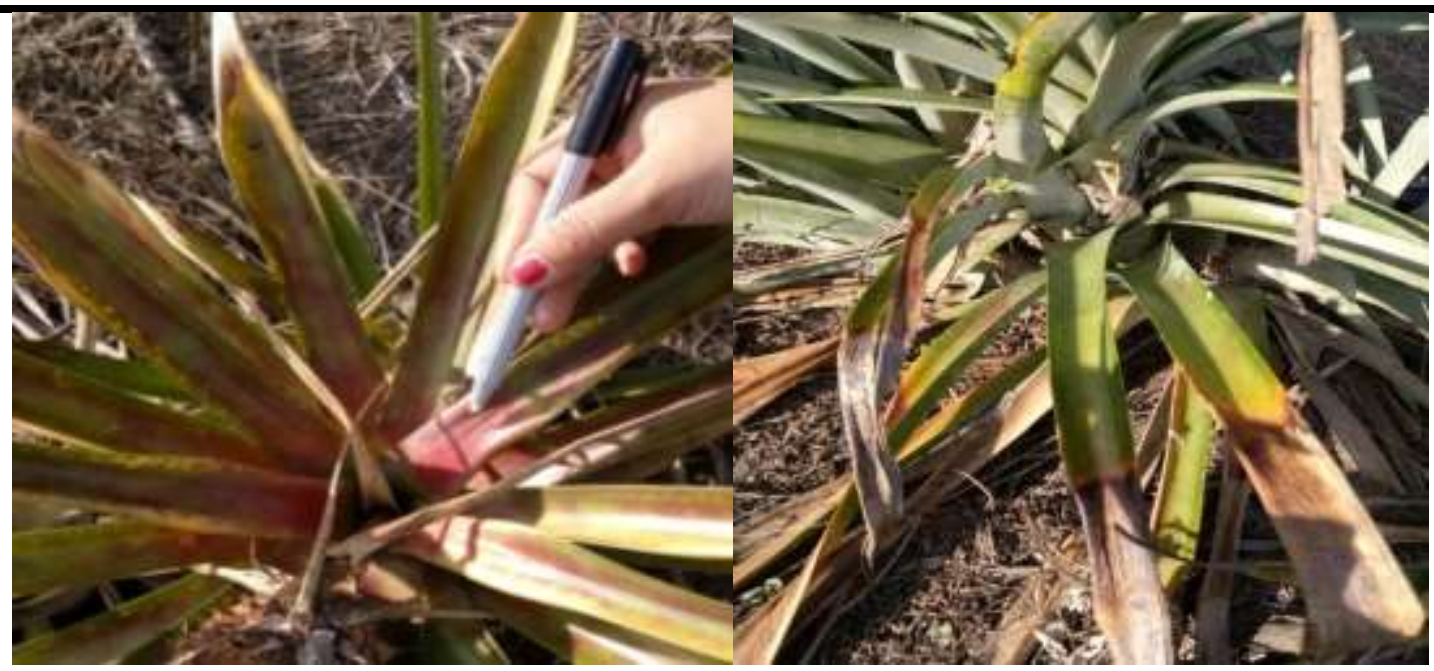

Fig.5.a. Red wilt symptoms

5.b.Symptoms of wilting curling and dead tip

In this area, there are three gardens observed and the three pineapple gardens are seen to be infected with wilt disease with disease severity for each garden averaging 50-60\%.

\subsection{Incidence of wilt disease in pineapple production center of Pangaribuan Sub-district (Lobu Gala Village)}

Planting pineapple in the District Pangaribuan Village Lobu Gala commonly planted farmers are the type of Smooth Cayenne

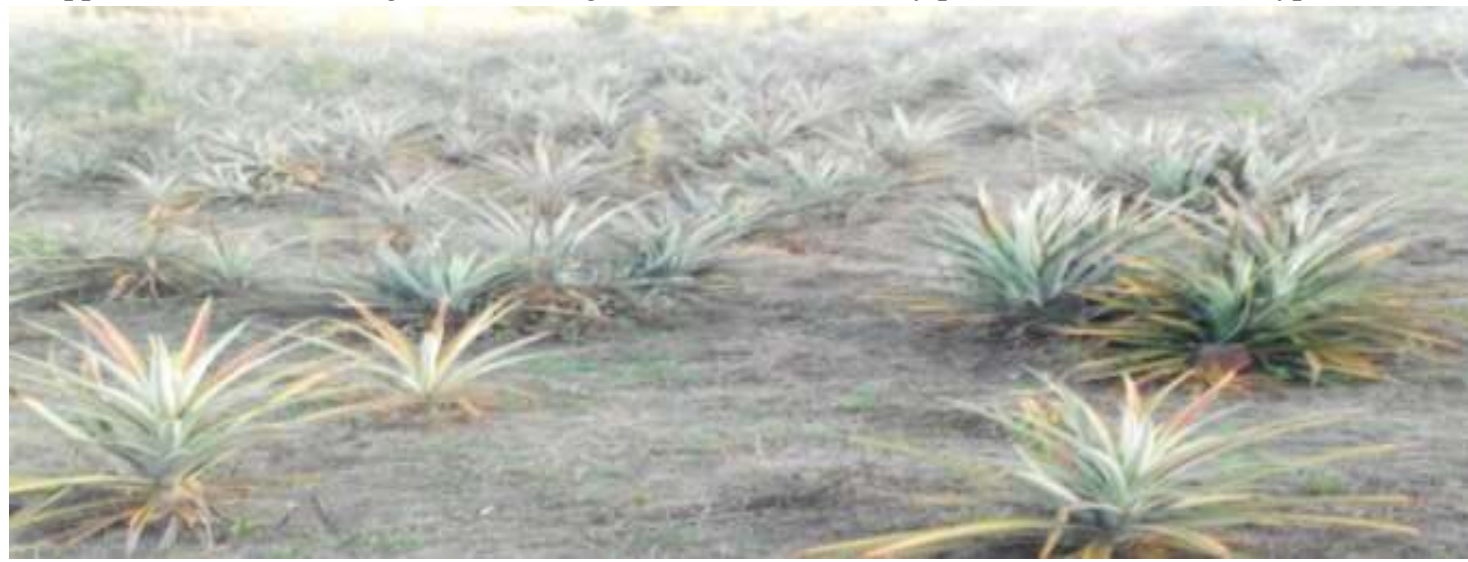

Fig.6: Location of pineapple plantation in District Pangaribuan Village Lobu Gala

In the pineapple plantation of Lobu Gala Village Pangaribuan subdistrict wilt symptoms are also quite commonly found. In this area, there are three gardens observed and on the three pineapple gardens are seen many pineapple plants are infected with wilt disease. The most noticeable wilt symptoms are symptoms of red and curling. The severity of wilting disease in Pangaribuan area is already high, about $80 \%$ already.

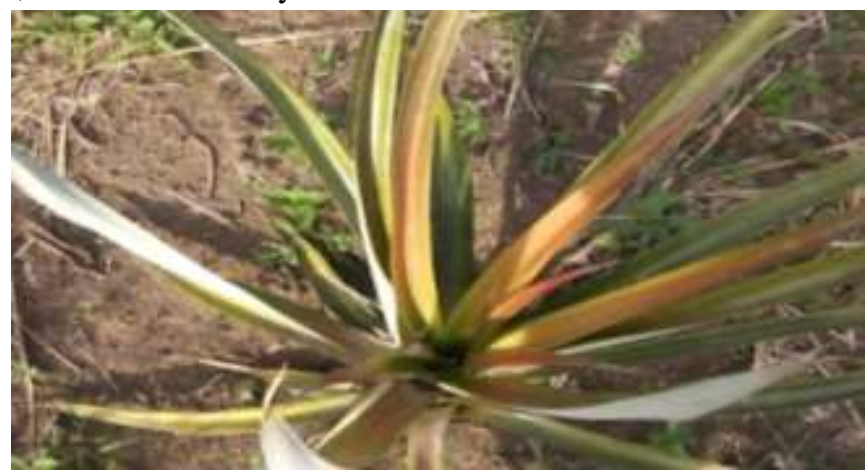

Fig.7: Pineapple plant symptomatic with red in pineapple plantation Pangaribuan District 
In addition to red wilting symptoms, there are variations of wilting symptoms of yellow wilt symptoms, curl / curling and dead leaf tips. The three variations of wilting symptoms can be seen in Figure 8 below:
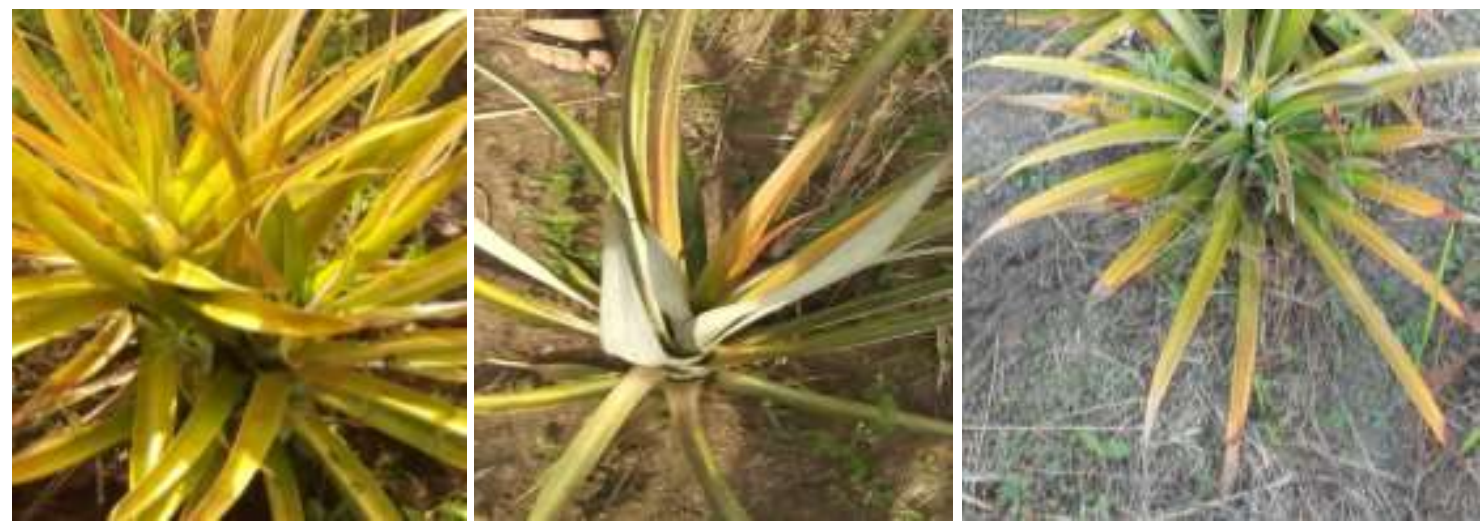

Fig.8: Variation of wilting symptoms: 1. Yellow; 2. Curl ; 3. Dead end

2.3. Incidence of wilt disease in pineapple production center of Siborongborong Sub-district (Hutabulu)

Pineapple is grown in this district is pineapple varieties Smooth Cayenne, with large pineapple fruit (weighing more than 2 $\mathrm{kg}$ ), it feels a bit sour fresh and the flesh is full of fiber. Pineapple is more often canned because the flesh is not easily destroyed.

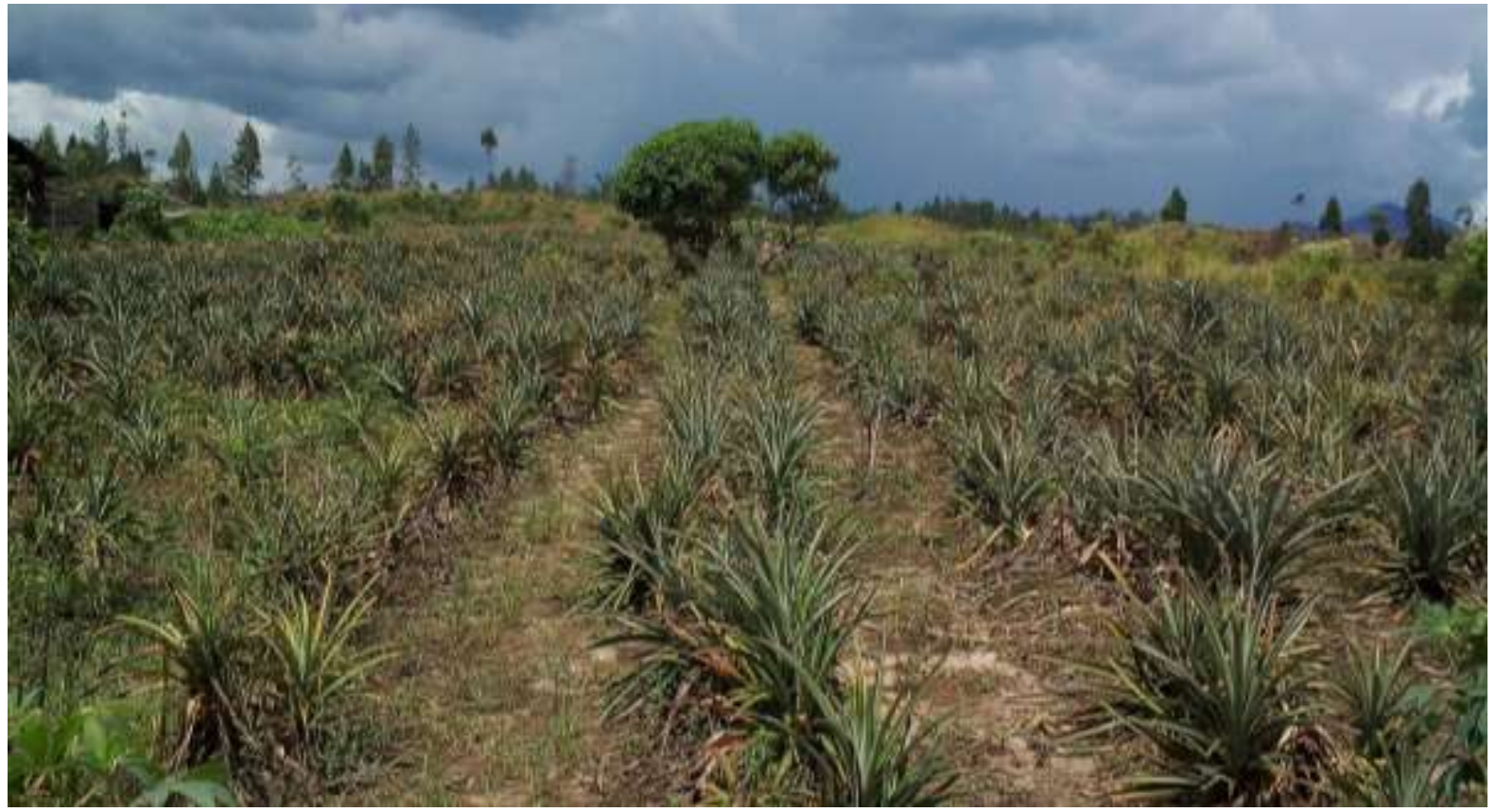

Fig.9: Location of pineapple plantation in Hutabulu village, Siborongborong sub-district

In this pineapple planting, wilt symptoms are also found quite a lot. But not as much in Tarutung and Pangaribuan area. In this Siborongborong area, there are four gardens observed and on the four pineapple gardens, two orchards of which there are almost no symptoms withered. While in two other pineapple gardens seen a lot of pineapple plants infected with wilt disease. The most noticeable wilting symptoms are yellow wilt symptoms (figure 9). The severity of wilt disease in Siborongborong is quite high, reaching $60-70 \%$ on average. 


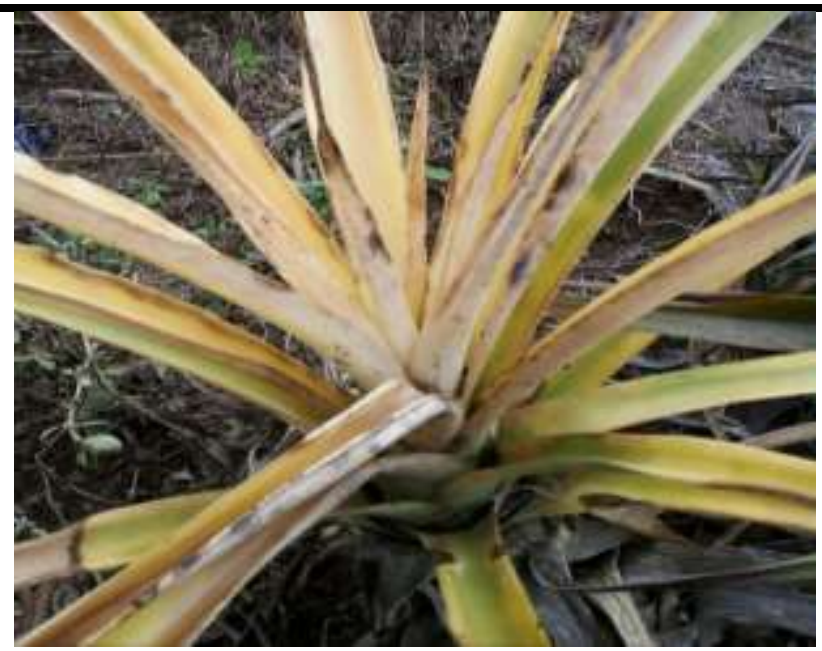

Fig.10: The pineapple plant is symptomatic withered in Siborongborong pineapple plantation

Symptoms of wilt in this area are more commonly found in pineapple plants generative phase. In nurseries and young pineapple plants are rarely found withered symptoms. In Hutabulu Village, Siborongborong Subdistrict, there are two kinds of variation of wilting symptom that are symptom of wilting with red and withered yellow. Both variations of wilting symptoms can be seen in Figure 11 below:

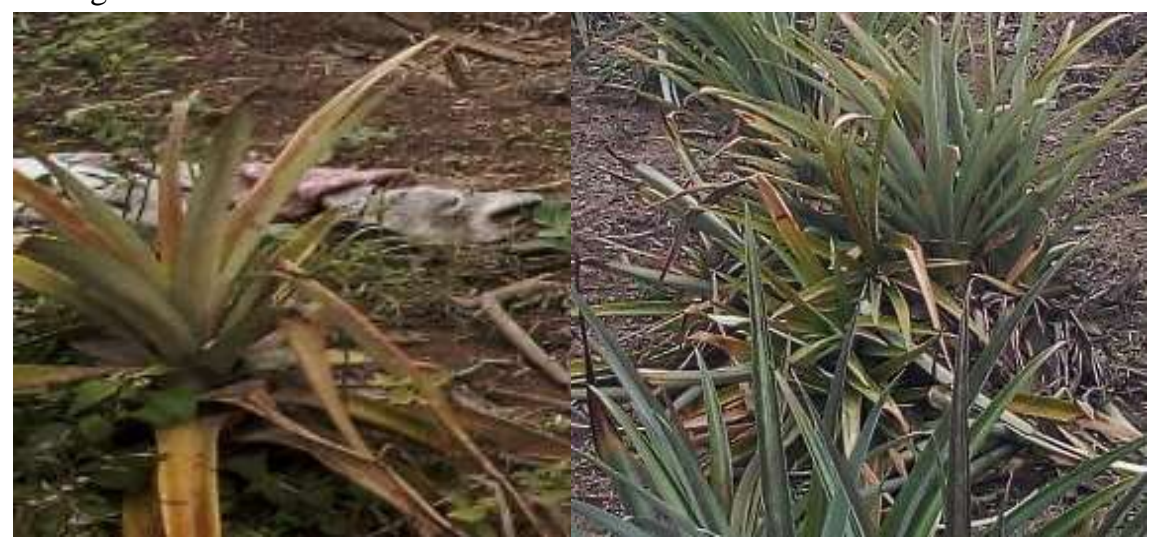

Fig.11: Variation of wilting symptoms. 1. Red; 2. Yellow

In all pineapple plants observed and those with wilting symptoms, colonization of mealybug was found at the base of the pine plant stems, in the lower leaf axilla or in the root of the plant (figure 12)

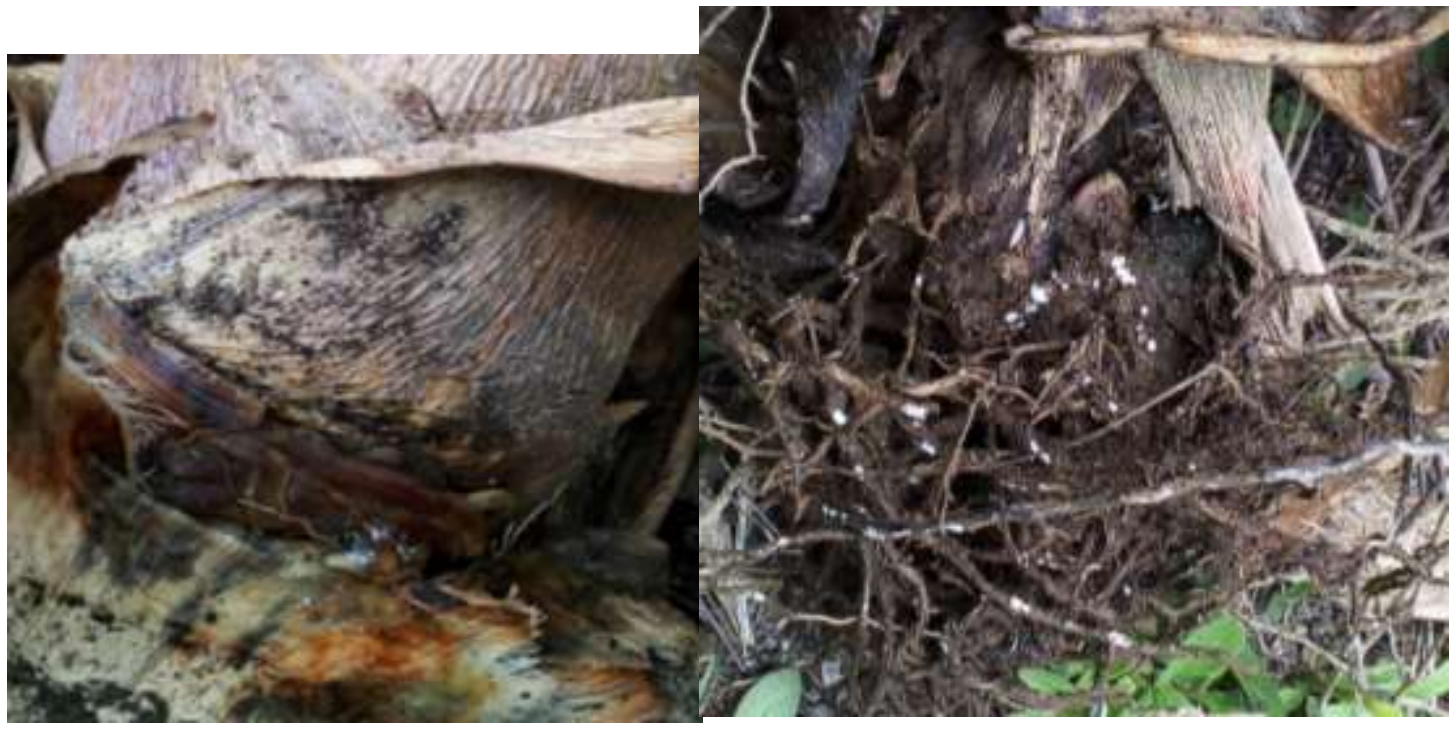

Fig.12: Mealybug colonies (Dysmicoccus brevipes) 
Of the three sub-districts of pineapple production centers observed in North Tapanuli District, it was found that the highest incidence of wilt disease was in the Pangaribuan area (Lobu Gala) with the severity of the disease reaching $80 \%$. This happens probably because the Pangaribuan area is at a higher altitude with high rainfall as well. So with the height of place and climate is optimal for the development and spread of this wilting disease. The lower incidence of wilt disease from the three central pineapple provinces observed was in Tarutung sub-district (Desa Siarang-arang) with incidence of wilt disease around 50$60 \%$.

\section{CONCLUSIONS}

1. Mealybug infestation (D. brevipes) can aggravate and accelerate the onset of wilting symptoms, but is not a major factor in triggering symptoms of pineapple crops.

2. Mealybug wilt disease in pineapple plants has been found widespread in pineapple production centers in North Tapanuli District.

3. Almost all pineapple plants attacked by wilting disease and difficult to find pineapple plants that are free of wilting disease.

\section{REFERENCES}

[1] CABI [Central for Agricultural and Biosciences International]. 2013. Crop Protection Compedium. Wellingford: CAB International.

[2] Collins JL. 1960. The Pineapple. London: Leonard Hill.

[3] Hu JS, Sether DM, Ullman DE. 1996. Detection of Pineapple Closterovirus in Pineapple Plants and Mealybug Using Monoclonal Antibodies. Plant Pathology 45: 829-836.

[4] Pretty GJ, Stirling GR, Bartholomew DP. 2012. Pests of Pineapple. dalam Pena JE, Sharp JL, editor Tropical Fruit Pests and Pollinators. Wellingford: CAB International. Hal: 15-195.

[5] Sipes BS, Sether DM, Hu JS. 2002. Interaction between Rotylenchus reniformis and Pineapple Mealybug Wilt associated Virus-1 in Pineapple. Plant Disease 86: 933-938.

[6] TUDA. 2015. Tapanuli Utara Dalam Angka. Badan Pusat Statistik. Kabupaten Tapanuli Utara.

[7] William DJ, Watson GW. 1988. The Scale Insect of The Tropical South Pacific Region Part 2: The Mealybug (Pseudococcidae). Wallingford: CAB International. 